\title{
A FOND REMEMBRANCE OF EDWARD B. WILKENS, RUTGERS' FIRST PLANNING PROFESSOR
}

\author{
BY HARVEY S. MOSKOWITZ
}

Mr. Moskowitz, Rutgers '54, is a planning consultant in the State of New Jersey.

\section{A Personal Introduction}

I enrolled in Rutgers College in September I950, hoping to graduate in June I 954 with a degree in electrical engineering. All engineering students took the same curriculum during their freshman year, and only in their sophmore year did they begin to specialize. As part of our first year's program, we were required to attend lectures given by representatives of each of the engineering departments-electrical, chemical, civil, etc. The idea was good-many of the freshman had no idea as to what engineering speciality they were interested in. I remember talking to one freshman who picked electrical engineering because he thought he would be able to fix his television set when he graduated. ${ }^{\mathrm{I}}$

One of the orientation lectures was given by a tall, crew-cut professor by the name of Edward B. Wilkens - "Doc" Wilkens to faculty and students. His pitch was for city planning engineering. Rutgers was, at the time, one of only three colleges offering undergraduate degrees in city planning engineering. ${ }^{2}$ In fact, in I 950- I95 I, only I 9 colleges were offering graduate degrees in planning. ${ }^{3}$ Wilkens' lecture was full of slides, a device he used with great effectiveness in all his courses. He talked about city planning as the field for the Renaissance Man, a term which probably meant nothing to most of the fledgeling engineers listening to Doc's somewhat high-pitched voice and frequent laugh as he told funny stories about planners and politicians. His point was effective, at least to this listener: Planning was a field which encompassed engineering, architecture and design but also relied on law, economics and political science. The planner might be called upon to design a housing layout, come up

\footnotetext{
I What was even funnier was the fact that the representative of the electrical engineering department in his orientation lecture emphasized the fact that when you get your EE degree you probably wouldn't be able to fix your own T.V. I don't know what happened to the student.

2 Perloff, Henry S., Education for Planning, City, State and Regional, Baltimore, MD., The Johns Hopkins Press, 1957, p. I9.

3 Ibid., footnote 15.
} 
with the costs and benefits, and then sell the project to the elected officials.

City planning sounded interesting, and I asked Doc whether I could take the Introduction to City and Regional Planning course during my 2nd semester of my first year instead of waiting for my sophmore year. That could be arranged - typically Doc in encouraging students into planning and doing what was necessary to move the bureaucracy to waive the rules. ${ }^{4} \mathrm{I}$ took the introductory class and eventually all the others, getting my degree in I 954 as planned, but not in electrical engineering. Over a 32-year time span I worked for county planning agencies, private consultants and state government. In I 966, I opened my own consulting firm. Until he died in 1985, Doc Wilkens was a teacher and friend. When I was in the United States Air Force ( I 954- I 956), he and his wife, Audrey, sent me cookies for holidays and wrote and insisted on long letters describing new cities, places and experiences. He was responsible for my career and consequently shaped my very life.

While Doc was personally important to me, he also had a significant impact on planning in New Jersey and Rutgers University. In fact, the very design of the Alexander Library could be attributed to Doc Wilkens-but that's for later. This article discusses Ed Wilkens as a planner and educator, and Doc's impact on Rutgers and New Jersey. Much of the information and research comes from the books, notes, slides and course material recently acquired by the the Department of Special Collections in Rutgers' Alexander Library. They provide valuable insight into early planning in New Jersey, a progressive planning educator many years ahead of his time, and warm reminiscences of a friend and colleague.

\section{Wilkens As Planner and Educator}

Edward Burkhardt Wilkens was born in New York City on February 8 , I 9 I I and died November 7, I 985 . He received a BA from Columbia College in I 932, a Bachelor of Architecture degree in I 935, and a Dottore of architecture from the University of Rome in I937. He returned to Columbia in 1939 for his MS degree in City and Regional Planning. In I 935, just prior to leaving for Italy, he married Audrey Thompson, who still lives in the same home that they bought when they moved to New Brunswick in 1946.5

\footnotetext{
4 Because of the small number of students in the planning curriculum-never more than ro in the years the author was in school-students were enrolled in whatever planning classes were given that year. The program consisted of 2 I credits in seven courses. Students were constantly called down to the Registrar's office to explain why, as juniors, they were taking a senior design course.

s I am indebted to Mrs. Wilkens for the many hours she spent with me and answering questions about her husband in the preparation of this article.
} 
Wilkens' professional career was diverse and geographically widespread. He practiced architecture only briefly. He designed public housing in Red Hook (Brooklyn) in I 937 and a privately-built garden apartment project in Arlington, Virginia in 1938. But he was not particularly interested in architecture and, as he pointed out to his classes, architecture was not a growth industry in the depression.

With his graduate degree in planning, Wilkens began his professional career in I 939 as planner for the Town of Nutley, New Jersey. In I 940 and I 94 I, he became supervisor of the Virginia State Planning Board and one of his accomplishments was a publication entitled, "A Report on the Defense of the Hampton Roads Area" (June 30, I94I). The report, now in the Rutgers archives, called attention to the physical congestion in the "vital defense area" and the need for immediate expansion of planning operations in the area.

The Report may have overstated the case for planning when it noted:

The deadliest saboteur of national defense which our rearmament program has encountered to date is not the fifth columnist, not the striker in defense industry, not the shortage of strategic materials-it is congestion and confusion in the centers of defense production . . . in the face of an enemy whose main strength lies in his extraordinary powers of planning and integrated execution of large and complicated operations. The weakness of our own program in this regard is the cause of grave misgiving and alarm. . . . it is admitted by all that the success of Hitler to date is due to six years of preparation plus sound planning; yet this country is endeavoring to defeat Hitler on the basis of two years of preparation without sound planning . . .

Then again, the report also contained a letter of transmittal to President Roosevelt from Governor James H. Price emphasizing the urgency of planning in the Hampton Roads area.

From I94I-I943, Wilkens was planning engineer for the County of Henrico, Virginia. He remained until i 943, when he became chief planner for the City of Buffalo, New York. The Buffalo job ended in I 944 when he became a senior planner with the Public Administration Service (PAS) in Chicago. During the two years he was with PAS, Wilkens worked as a consultant to the states of South Carolina, Michigan, and Alabama as well as the City of Phoenix, Arizona and Town of Cicero, Illinois.

His diversity of experience served him well. He made copious notes and took many pictures of the various towns, which he subsequently used in his courses as real-life examples of planning problems and situations. 
His penetrating analysis, often in a narrative rather than in an analytical mode, provided sharp insight to problems and possible solutions. It carried over in his teaching when he constantly urged students to make notes and record their first impressions when starting in a new town or city.

During his PAS days, Wilkens published or prepared early drafts of the only two non-project-related articles that he wrote. One was for the American Society of Planning Officials (ASPO) in 1945 and was entitled, "Evaluation of State Legislation in Planning and Urban Redevelopment." In I 948, "Mapping for Planning" was published by PAS based on studies done when he was with PAS. "Mapping for Planning" is long out of print but was used for many years by planners for map presentations. The latter publication also reflected Wilkens' emphasis on the practical side of planning. The late Isadore Candeub, president of Candeub, Fleissig \& Associates, which at one time was the largest planning consulting firm in the nation, specifically sought out Wilkens graduates. His comment about Wilkens' students was classic: "They were eminently and instantaneously billable." He went on further to say that a Wilkens'taught planner didn't need six months of deprogramming and six months of reprogramming before he could put them in the field. ${ }^{6}$

\section{Wilkens the Educator}

In 1946, Ed Wilkens came to Rutgers as Professor of Regional \& Urban Planning and to the Middlesex County Planning Board as Director of Planning. His salary for the first year was $\$ 5$,000-equally shared by Rutgers and the County. His part-time status remained until r 954 when he left the County and in addition to his teaching duties, started the Rutgers Planning Service ( I 954- I 958) which provided planning services to local municipalities and non-profit agencies. In i 958, he left the Rutgers Planning Service and became director of campus planning, coordinating development plans of all Rutgers campuses. ${ }^{7}$ In 1972, Wilkens shifted from the College of Engineering and Livingston College to Cook College as Professor of Environmental Planning. He retired in 1976.

The Rutgers planning program as developed by Wilkens consisted of 2 I credits generally broken down as follows:

$\begin{array}{ll}\text { Introduction to City \& Regional Planning } & 3 \\ \text { Planning Laws } & 3 \\ \text { Planning Design I } & 6\end{array}$

${ }^{6}$ Private conversations with Candeub.

7 The Rutgers Planning Service may have ceased operation when Wilkens left. No record of its operation exists subsequent to 1958 . 
$\begin{array}{lr}\text { Planning Design II } & 6 \\ \text { Planning Seminar } & \frac{3}{21}\end{array}$

It was the first program of its type in the country, and it was administered by the Department of General Planning in the College of Engineering. ${ }^{8}$ Students in economics, political science and geography could also take the same 2 I planning credits and graduate with BA degrees.

The two design courses were each one-year courses and formed the basis of the program. They involved a significant number of assignments fashioned in a variety of ways. For example, a semester long project might involve the design of a planned unit development for hundreds of acres, various land uses, and involve a team rather than a single student. At least once each semester, week-end charettes were planned. ${ }^{9}$ Without any opportunity to prepare, students would arrive on Saturday morning and find topo maps and other material for a site of anywhere from 5 to 50 acres for which they were asked to do a design. The finished product had to be turned in before Monday morning. It was fun and intensive and prepared graduates for the real life "all-nighters" - getting projects completed for clients.

Wilkens encouraged experimentation. One project called for the design of a high-rise project, and Wilkens asked for volunteers to render the final drawings in wash (watercolor). Four of us volunteered, and we met at his home on a Sunday morning where he had set up four easels in the back yard. After a quick explanation of the technique (very messy and with little room for error), we experimented until we felt comfortable. We then used it to render the drawings with various degrees of success. Two things stuck out-the case of cold beer that we drank that day and Audrey Wilkens' spaghetti dinner that night.

The design courses were critical to understanding the planning process. By and large they involved actual undeveloped parcels of land around New Brunswick. The studies required on-site visits - also emphasizing one of Ed's major theories: You can't plan from an officie. He insisted on site visits and suggested that planners be required to visit projects they designed after they were built to see what worked and more importantly, what didn't.

Wilkens' class assignments were imaginative. One was to design a zoo.

${ }^{8}$ Dean's Page, Rutgers Engineer, 1963-1964, March. In the Wilkins papers, Alexander Library.

${ }^{9} \mathrm{~A}$ charette is a design assignment required to be finished in a specific period of time. 
He said a zoo was a miniature city with a mix of land uses disguised as animals, circulation problems and various infrastructure needs. Naturally, it required a site visit-so the class went to the Philadelphia and Bronx zoos before starting. In designing urban neighborhoods, the class went to New York City and discussed and analyzed the vitality of Greenwich Village, the sterility of some of the major urban renewal projects, and the grandeur of Rockefeller Center and what made it special.

The key to Wilkens' extraordinary success as an educator, at least in the early years, was the tie-in he provided with Middlesex County. Almost every student, at least from 1946 to I954, worked for the County. Even after Wilkens left, subsequent directors Harry Letson and Russell Montney, for example, used Rutgers students extensively. We were paid the minimum wage of $\$ .75$ per hour the first year which was then raised to $\$$ I .OO per hour the second year. The workload was varied and was as little or as much as the student preferred. Since there were generally fewer than 20 students enrolled in the program during most of the early years, there was plenty of work.

Work assignments also varied. Students were expected to run the copier and type if and when the need arose. There was a lot of drafting work, including preparation of maps showing basic data-topo, soils, traffic flow, etc. The major work load, and the most valuable in terms of practical application, was review of site plans and subdivisions. ${ }^{\circ}$ Under the New Jersey County Enabling Act, all site plans and subdivisions on county roads or affecting county drainage structures had to be approved by the county. Since the stormwater runoff from all land eventually reached a county drainage structure, such as a pipe or culvert, from a practical point-of-view all site plans and subdivisions were reviewed by the County Planning Board.

Students were often assigned geographically — possibly handling two or three towns under an experienced planner or even a second year student. The subdivision or site plan review included site visits and determining whether the plan met the requirements of the local ordinance and the county regulations. Students quickly became knowledgable and conversant with local zoning and subdivision ordinances. Designs were reviewed to ensure they met good planning standards and finally, the findings were written up as part of technical memos sent to the municipality

so A site plan is a development plan for a specific piece of property. For example, a garden apartment development or shopping center would be shown on a site plan. A subdivision is the division of a lot-whether to sell a three (3) foot strip to a neighbor or dividing a 100 acres site into I 50 lots for houses. 
and the applicant. In some cases, applicants came to the County Planning Board offices and discussed specific recommendations.

The experience garnered from working with the Colinty was enormously valuable. Students were functioning as planners-reviewing, designing, writing and meeting applicants. They attended board meetings and addressed the public. It was the kind of training that prompted Candeub's "eminently and instantly billable" remark.

In addition to the review of site plans and subdivisions, students also functioned as local planners working with various Middlesex County municipalities. Under the auspices of the County Planning Board, and in conjunction with some of the studio courses, students prepared master plans for local municipalities. These still exist and are part of the Wilkens archives. In Cranbury, for example, a I 960 master plan prepared by a design team of students discussed preservation of the Historic Village of Cranbury, industrial areas, and suburban development-problems still facing the Township in 1989. Again, students performed as planners, researching and writing, with the opportunity to present plans and receive feedback.

Students working for local municipalities were not entirely favorably received by all segments of the planning community. The Wilkens papers include a letter from Murlin R. Hodgell, Chairman of the Department of City \& Regional Planning, to Dean Elmer C. Easton of the College of Engineering. ${ }^{11}$ Evidently Easton had received a letter from the New Jersey Association of Consulting Engineers complaining about planning students working for local communities. Hodgell's letter read in part:

Every planning student during his training needs exposure to the politics, pressure groups and mixtures of highmindedness and prejudices which are involved in the decision making process of local government. These are things that cannot be effectively duplicated or 'taught' in a classroom. Yet an understanding of how to develop, sell and carry out responsible professional studies within the context of such democratic manipulations is at the heart of the planning process.

\section{Wilkens the Planner}

In addition to having a full schedule as an educator, Wilkens became Director of Campus Planning in 1958. Rutgers had, over a period of

" A new Department of City \& Regional Planning was established in 1962-1964 with authority to grant Masters and Ph.D. degrees, and the bachelor's program in city planning was phased out at the same time. Wilkens declined an opportunity to be considered as chair and Murlin R. Hodgell, an engineer, architect and planner from Kansas State, was selected. 
years, prepared master plans to guide campus development. In 1927 , one of the nation's foremost planners, Harland Bartholomew, himself a Rutgers graduate ( I 9 I 3), prepared a master plan of the New Brunswick campus. In December I 959, the second Bartholemew Plan was prepared, submitted to the Board of Trustees and approved. Ed Wilkens was given the responsibility to carry out the plan. It pinpointed the location of a number of buildings which were financed out of the bond issue of I 959 . The Bartholemew Plan recommended the construction of the dormitories along the Raritan River, Scott Hall, the new Education Building, Language Laboratory Building, additions to the gym, Stonier Hall, University Commons, the dormitories on Bishop Campus and the infirmary building.

In I 962, the Department of Campus Planning under Wilkens prepared an updated master plan. It located the site of the School of Library Science, the new College Center building, and designated other areas of expansion on the campus. It was this plan which resulted in the acquisition of a substantial number of small individual houses and flats along Morrell Street. In I 969, the Plan was again updated by the Department of Campus Planning. The I 969 Master Plan was significant in that it established for the first time a formal limit of expansion and land acquisition on the College Avenue Campus. Wilkens also worked on master plans for Bush Campus, and the Newark and Camden campuses, as well as Cook College. He worked on specific building locations for Livingston College. According to Peter Toliscious, who served as Wilkens' assistant in the Campus planning office, most of the development of the Rutgers campuses between I 958 and I 97 I was under Wilken's direction.

\section{Wilkens' Legacy}

Doc Wilkens spent 26 years (I 946-1972) teaching city and regional planning at Rutgers. In many respects, he was ahead of his time. $\mathrm{He}$ stressed the practical aspects of the profession, and he insisted that students work on real-life problems in real-life situations. He said that his students would never be surprised with the real world of planning because they experienced that world in his courses. He constantly admonished us not to waver in our standards but to recognize that they could be met in different ways, and often not all at once. He firmly believed in listening to the public and working out mutually acceptable solutions to planning problems.

Consider the timeliness of those ideals: In a 1984 article in the Journal of Planning Education and Research, Lawrence Susskind, professor of planning at MIT, stated: 
We need, I think, a more even-handed emphasis on problem-solving skills to match our focus on critical analysis. It does little good to train a cadre of social critics immobilized by their own analytical powers. We must stress the teaching of negotiation, mediation, and other collaborative problem-solving skills. We should be building each student's sense of self-confidence-imparting the kinds of strengths needed to propose and take action even in the face of overwhelmingly difficult odds (emphasis added). ${ }^{\text {t2 }}$

Wilkens also admonished his students not to take themselves too seriously. He often said that the ability to laugh at one's self was a principle prerequisite for self-preservation. He had that ability. In the archives are several beautiful renderings Doc did as an architectural student. ${ }^{13}$ One of these is of Greek ruins entitled Capital of Tholos at Epidarios, which shows a section of a column and rooms. On the right side of the rendering is a small urn with what first appears to be unreadable markings. With a magnifying glass the inscription reads: "Roses are red and violets are blue. Give me first mention place, and I've got ten bucks for you." $\mathrm{He}$ also designed a series of awards to planners and to planning boards. They were designed to deflate the more pompous planners and to recognize the very human characteristics of local boards. (See Figures I and 2)

Wilkens was a firm believer in continuing planning education for planning board members. In the early I950's, along with other agencies, ${ }^{14}$ Wilkens started the first local planning and zoning courses for New Jersey planning board members. The Wilkens papers include an early prospectus which list the instructors for the first "Inservice Training Course, Principles of Planning." The list reads like a Who's Who of Planning: Wilkens; McKim Norton, Vice President, Regional Plan Association; and Robert C. Hoover, Planning Director, Morris County Planning Board. Subsequent courses were taught by Hugh Pomeroy, Westchester County Planning Director; Harry Sears, prominent land use attorney; and Robert C. Weinberg, professor of planning at NYU.

In the final analysis, the legacy of Doc Wilkens rests with his students. As near as can be determined, Wilkens taught close to 300 students in his

I2 Susskind, Lawrence, "I'd Rather Invent the Future than Discover It," Journal of Planning Education and Research 3, Winter 1984.

${ }_{13}$ One of the renderings, a Mayan Temple, won an Honorable Mention in the prestigious world-wide Beaux Art Competition. It now is located in the Zimmerli Art Museum.

${ }_{14}$ The Rutgers Bureau of Government Research and University Extension Division, in cooperation with the New Jersey Federation of Official Planning Boards (now the New Jersey Federation of Planning and Zoning Boards), New Jersey State Department of Conservation \& Economic Development (now DEP and Department of Community Affairs) and the New Jersey State League of Municipalities. 
18

THE JOURNAL OF THE

Figure I

AWARDS FOR PLANNERS
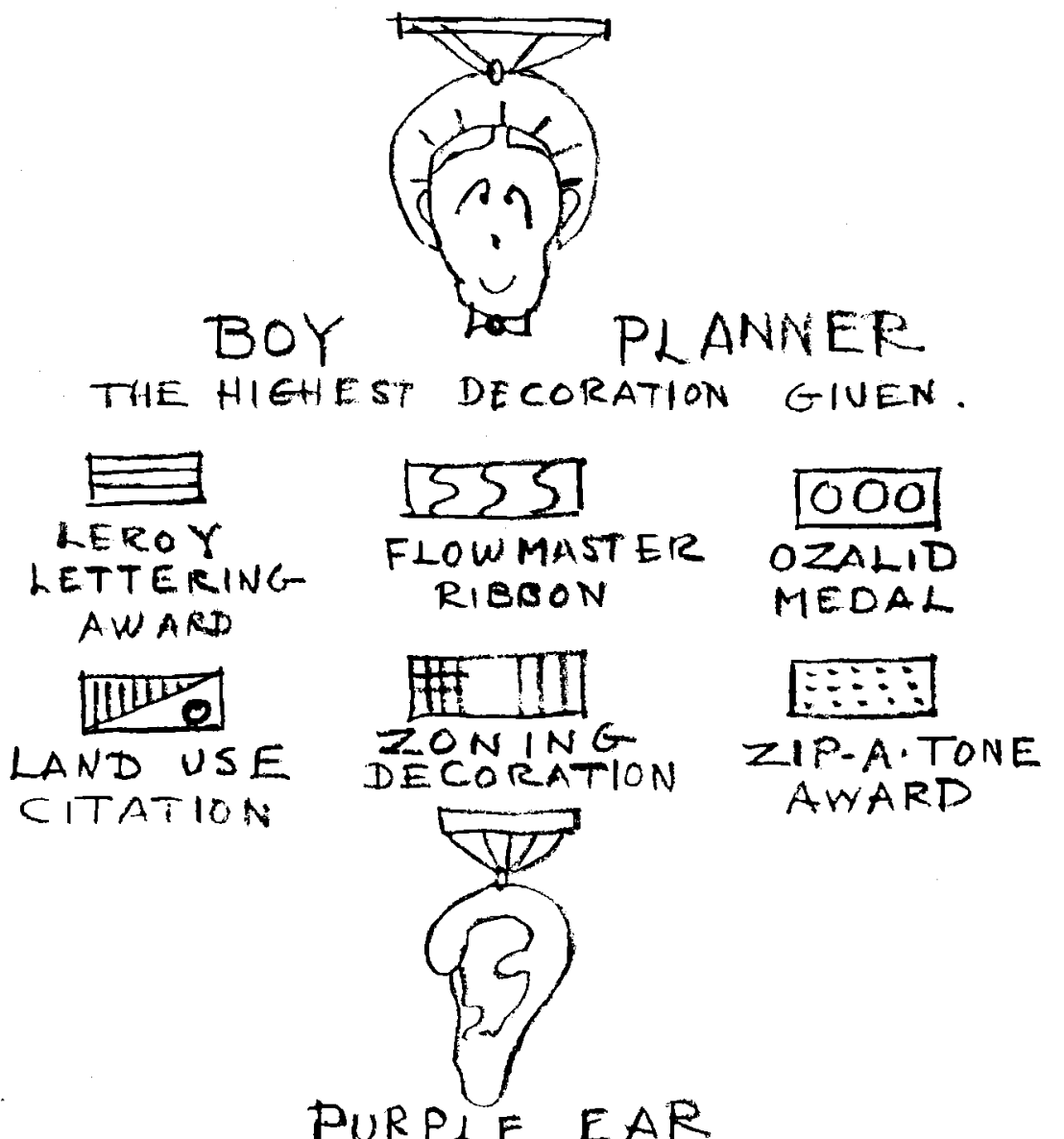

$\left\{\begin{array}{l}\text { PURPLE EAR } \\ \text { For ears bent beyond the call of duTy by }\end{array}\right.$ exposure to political flak. 
Figure 2
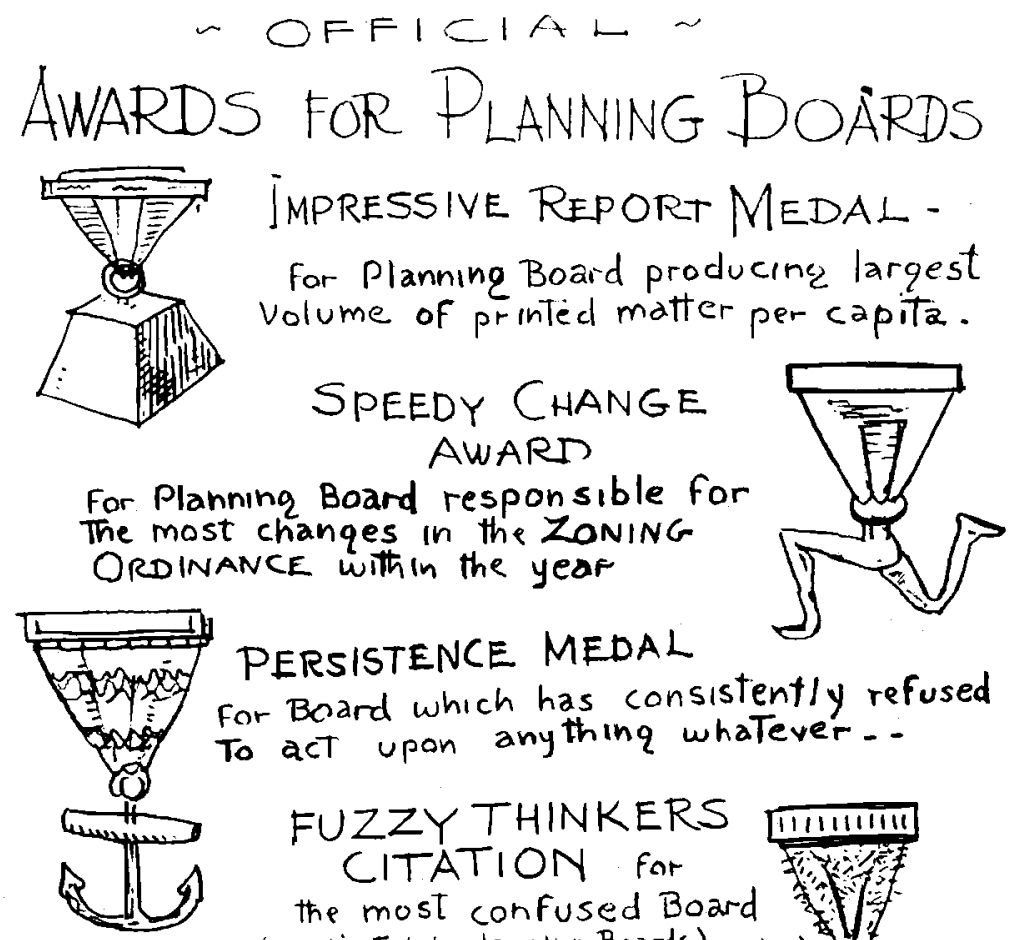

PERSISTENCE MEDAL

For Board which has consistently refused To act upon anything whatever.-

$$
\begin{aligned}
& \text { FUZZY THINKERS } \\
& \text { CITATION For }
\end{aligned}
$$

the most confused Board (not limited to planning Boards)

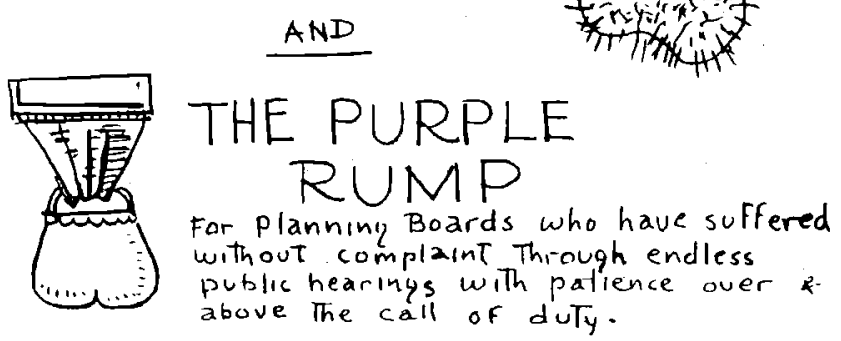

26 years at Rutgers. ${ }^{\text {I5 }}$ As important as the professional skills were the moral attributes and sense of humanity that he possessed and taught. Many of his students became planning directors of municipalities and counties and others went on to teach at the college and university level.

In preparing this article, I met with Dr. George Sternlieb, former head of the Rutgers Center for Urban Policy Research and distinguished

is In the early years, some classes had fewer than five students. 
urban planner, and Professor Jim Hughes, a Wilkens student and former head of the Rutgers Department of Urban Planning. It was just before the New Year, and we went out and brought back some lunch along with a bottle of wine, a method of teaching Ed Wilkens would have appreciated. I flipped on my tape recorder and asked if they would share with me their thoughts on Edward B. Wilkens. They graciously did so, and what follows are some of those thoughts:

Dr. Sternlieb: I knew Ed all too briefly as a colleague. In retrospect I think I appreciate him more now than I did at the time because what Ed provided was a sense of continuity . . . a vision of the past brought to the future, not stick-in-the-mud conservatism, but rather the sense of history. Ed was, in his own quiet way, very profound and enormously well-educated (by himself, I should stress here). He had gone through all the appropriate degrees and the like but, in addition, he was very well read and perhaps even more than that, well thought-through. He was also very deft. Again, in retrospect, one appreciates these things more. He was . . . a non-directive but persuasive advocate for stepping back a little . . . and viewing a proposal or development, not merely in terms of the here and now, but what its going to look like twenty years into the future or perhaps even longer.

Dr. Hughes: I guess one of the things that distinguished him from most present faculty today was his ability to link theory with practice. When you went in to talk to him he knew what ws going on in the planning world and in the academic world. He could explain clearly why things were designed the way they were, and why things happened in the University or as a result of the University's planning. He knew what was going on in Middlesex County and New Jersey. He had enormous practical insight into the real world of planning. There are very few faculty today that have that facility of linking theory to reality.

Harvey Moskowitz: What Jim was just saying about the ability to link theory and practice is difficult to come by now. Part of it is the changing field, the nature of what planning is and what it was.

Dr. Sternlieb: Let me turn to that changing field. Ed was a man of very deep and profound culture, masking it somewhat in a casual fashion. He was fully competent to appraise the social factors that increasingly dominate the area, but never prisoner of them. Ed's feeling in this pseudoconflict between physical planner and social planner was that the role of a planner is to do planning. Ed was a great, gentle buffer between these two ogres. If I can voice what seems to me was implicit in his philosophy, it was before you become a philosopher king on what should be, at least 
become a good mechanic in terms of what the building blocks can produce for you.

Dr. Hughes: There's another dimension of Ed's that's worth noting. $\mathrm{He}$ had to operate in a very hostile environment. I remember he was given the charge in 1963-1964 to bring somebody in to head a graduate planning operation. They brought in an educator who was an architect, engineer and a planner, and he lasted at Rutgers just one year. That's the atmosphere that he faced. He made a presentation before the entire faculty of engineering on the plan to develop the graduate program in planning. The engineering faculty raked him over the coals. They were opposed to an independent, non-engineering planning department and as a result, the entire graduate planning program was delayed until 1967. Planning did not operate within a receptive faculty group. The engineers were opposed to a planning program that they didn't control, and when the graduate planning operation did start, it immediately got placed in Livingston College and became the favorite child. This was the era of the change agent, social planner and the like. Design became irrelevant. But this was not what Ed had envisioned, and he became somewhat disillusioned. All those years he really operated under a tremendous handicap within the University. He had no support, and the University didn't provide him with any real resources. Now when it finally came, the program was socially oriented rather than what Ed had taught.

Dr. Sternlieb: Picking up on Jim's comments, on resources and the like, Ed provided a leadership for planning in a University that really didn't quite know what to do with it. But to a certain degree, like Moses in the promised land, he never saw it but, at least he provided a home and a base which later flourished once the University decided to devote the money and resources. He was never the beneficiary of this. He had to make do with very little, and he made do very well.

Harvey Moskowitz: Changing the subject a little, I found him to be in his own way a charismatic individual.

Dr. Sternlieb: That's interesting. Our contemporary vision of who has charisma is fashioned by the likes of Donald Trump. Ed was a very gentle man. He would listen to just about anybody. If he believed in them he would go along with them very enthusiastically; if he didn't, he never put them down. He had a practically poetic vision of what planning was all about, coupled with technical confidence. And somehow or other we seem to have lost both of these ends of the spectrum.

Dr. Hughes: The point I remember about Ed Wilkens, a principle that he maintained throughout his career, was a vision and sense of continu- 
ity-that in planning for the future you really have to have some firm grounding, understanding and knowledge of the reasons of why and how the past was structured.

\section{Doc Wilkens and the Alexander Library}

I have left to the end what I think is the most fascinating part of Doc's career, and that's his involvement with the Alexander Library. In I 95 I, the Rutgers Board of Trustees announced construction of a new library to replace the venerable but hopelessly inadequate Voorhees Library (now the Jane Voorhees Zimmerli Art Museum). ${ }^{16}$ The firm of York and Sawyer, architects for Rutgers University, began work on the design. Wilkens was concerned that the library would be in the Georgian or Colonial mode, no different than the three postwar buildings constructed or still under construction on the New Brunswick campus-Demarest Hall, a dormitory, the Chemistry Building on University Heights ( I 948), and the then half completed Institute of Microbiology. ${ }^{17} \mathrm{His}$ position was that Georgian or Colonial architecture in I 952 was intellectually dishonest and reflected a shallow misguided attempt to emphasize the fact that Rutgers was a colonial college, chartered in I 766 . From a practical point of view, Wilkens said that designing buildings for specific purposes like a library, and attempting to shoe-horn them in a preconceived architectural mold, was expensive and inefficient. Finally, Ed Wilkens recognized that the University would soon be embarking on a massive construction program to accommodate a planned expansion and that unless the existing policy was stopped or shifted, we would, in his words, proliferate the architectural form he labeled as "bastard colonial." 18

Ed decided on a publicity campaign to get the Trustees to redirect the

${ }^{16}$ Targum, I1 $/ 20 / 5$ I, Vol. 93, No. I6, announcing that President Jones requested $\$ 2,000,000$ for first unit of new library.

17 It is difficult to determine why Wilkens thought the library would be Colonial. He was a close friend of Donald Cameron, the Rutgers librarian, but a review of the minutes of the Board of Trustees gives no clue as to the proposed design. The fact that all of the post-war buildings were Colonial and all were designed by York and Sawyer may have concerned him. In the November 2, I95 I issue of The Caellian-Targum, the proposed Football Hall of Fame building was featured-in Colonial design, naturally.

${ }^{8}$ The policy of constructing only Georgian or Colonial was evidently established by the Board of Trustees even before World War II. For example, the old gymnasium, built in the 1930's, and the Physics Building, built in the I920's, were Colonial. In a response to a series of articles calling for a change in the University's architectural policy, Aaron N. Kiff, York and Sawyer, stated: "Any architect works within the confines of a policy set up by his client. The policy of Rutgers University has been for many years that the buildings must be in the Georgian or Colonial spirit." (The Targum, April 29, 1952, Vol. 93, No. 41.) 
architects into a contemporary or functional mode. I introduced Doc to Mel Silver, a fraternity brother of mine who was managing editor of Antho, the Rutgers literary magazine. Silver's roommate was Morton Schlossman, editor-in-chief of the Targum, the bi-weekly publication of the "Men's College of Rutgers University, the State University of New Jersey." What was decided is described in an editorial in the April I 8, I 952 issue of the Targum:

\section{A WORTHWHILE EXPERIENCE}

For the next four weeks, beginning with this issue, Targum and Antho are cooperating on what both staffs believe is a worthwhile project. A series of articles by Mel Silver will be published explaining the concepts of colonial and functional architecture and how they have been applied to this campus.

The objective of the series is to show why the first unit of the new Library should be built in functional design instead of following the colonial pattern of the campus. It is the intention of this newspaper to arouse student feelings and opinion about this sorely-needed building, so that they should have a voice in its design. To this end all comments and criticism will be gratefully accepted and printed in the Letters to the Editor column.

We urge you to read Mr. Silver's views in Targum and Antho. They will prove both entertaining and enlightening.

The articles began in the April I 8, 1952 issue of the Targum and the first was headlined, "Modern Architecture Versus Colonial Style." It was followed by articles on April 24 ("Colonial Design Discussed"), May 2nd ("Modern Architecture Echoes Use and Site"), and May I $3^{\text {th }}$, the last issue of the school year, a guest editorial by Silver ("Ready, or Not?").

Silver's Targum articles appeared at the same time as his article entitled, "The Case for a Functional Library," appeared in Antho, the Rutgers literary magazine. ${ }^{19}$ The Antho article started off in a satirical fashion:

A short while back, I was seriously attacked by a novel type of bacteria. My resistance was low, and as a result, I became infected. I have been feverish ever since. My disease is extremely contagious and can be picked up by anyone who has courage enough to admit new ideas into his head. However, I must post a quarantine for those few individuals who either prefer to

${ }^{19}$ The Targum, Vol. 93, No. 38. 
examine only what they are allowed to examine or who prefer to examine nothing at all.

And there is something to examine! With the exception of Old Queens by the Chapel, Rutgers has managed to collect as representative a group of the most expensive, dishonest, inefficient, and uncourageous buildings ever brought together on any campus. And now, after seeing what has happened to Demarest Hall, and what is going to happen to the incipient Institute of Microbiology, I deeply fear for the outcome of our newly proposed library.

I do not want a traditional, classroom-corseted, symmetrical, and cumbersomely constructed statue of a building. I do not want a building that is inflexible and stands aloof from any demands of the future. I do not want an aristocratical building that stresses harmony-through-repetition, and that treats with equal emphasis classrooms, lavatories, and laboratories behind false facades, ashamed of the vital activities which are taking place within its ornamented walls. I want Contemporary Architecture!

But the article was prefaced by a serious note, quoting Donald Forrestar Cameron, University Librarian, as follows:

Nobody knows what the outside of a Library is supposed to look like. Most of them are imitations of other buildings such as railroad stations, gymnasia, and banks. We hope to design ours from the inside out, letting the functions of the Library determine, to a large degree, the architecture.

Silver's article included a sketch showing the various elements of a library and the interrelationship between the elements (See Figure 3). The editorial in the Targum, written by Silver, challenged the University:

. . Rutgers has a chance now to make architectural history for itself, to point the way as a leader among colleges by being able to exhibit the finest working library in the nation. The second is a more serious idea . . . Walter A. Gropius, Chairman of Harvard's School of Architecture, said . . . 'People get the kind of architecture they are ready for.' The question now is, Are we ready for a Contemporary Library? ${ }^{20}$

To what extent the campaign mounted by Doc Wilkens affected the design of the library is hard to say. The Rutgers University Board of Trustees, on April I 8, I 952, the date when Silver's first article appeared, heard from the committee on the library as follows: 
Figure 3
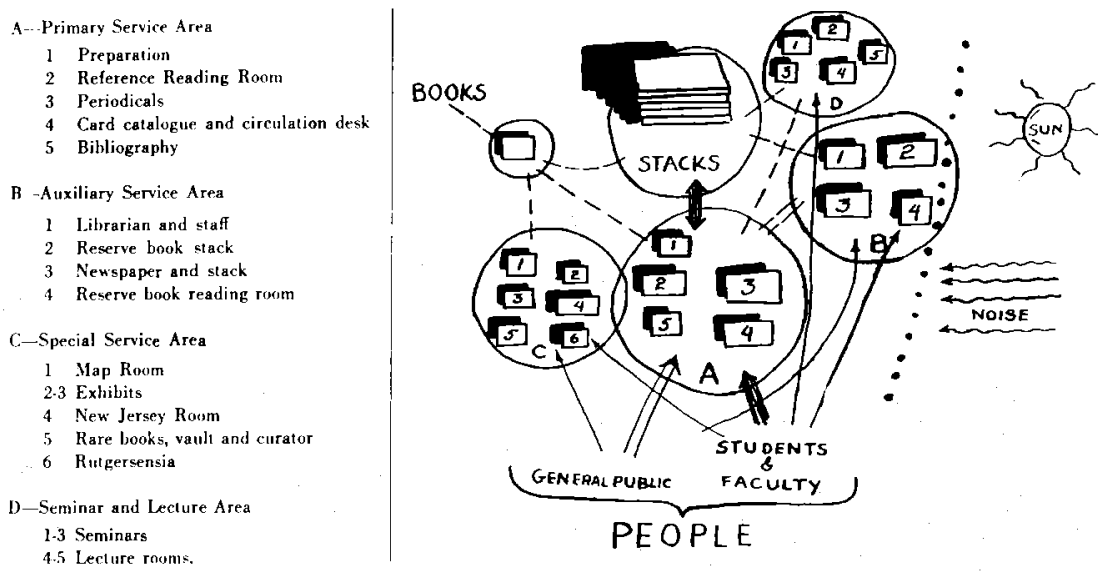

Dr. Nichols (Roy F. Nichols, chairman of the University's Trustee Committee and Dean of the University of Pennsylvania Graduate School) reported for the committee on the library, recommending that the new library be located in the area between College Avenue and Bleeker Place, south of Ford Hall and the Physics building, and giving reasons for this choice. The committee futher recommended that the architecture of the library need not conform to the Georgian pattern of recent buildings and that the architect of the new library be one who has either had experience with modern university library construction or have associated with him an architectural consultant who possesses such experience.

The minutes of the Trustees meeting of June 30, I 952 noted:

Mr. Shield reported that the committee on buildings and grounds and the committee on the library had held two joint meetings to discuss the problems involved in the location, design, and erection of the new library building. The committees had agreed to the following principles:

As to architecture:

The library must be a well designed building of some distinction which will fittingly represent Rutgers University, must be harmonious with the other buildings, must relate topographically itself to the site, and must add to the beauty of the campus;

The library should be planned as a library and built, so to speak, from the inside out; 
A committee of specialists to work with the librarian should be appointed to advise as to plans. . .

Mr. Shield further moved that York \& Sawyer be retained as architects of record and that the committees on buildings and grounds and the library be authorized to retain other architects as consultants, the total fee to be the usual charge to be divided between the firms by their mutual agreement.

The motion was seconded and unanimously adopted.

Discussion of the committee report was directed principally to the question of whether the proposed plans required a modernistic treatment of the exterior of the building. In answer to a question on this point, Mr. Shield said that the architects had no intention of presenting a starkly modernistic building but were aiming for a rich, fine, noble building with good materials worthy of the best architecture on the campus. $\mathrm{He}$ said that up to this time the architects have tried to discover a superior arrangement of the parts and organization of the building and that they plan to present studies of the exterior of the building at the next regular meeting of the Board. Mr. Shield reminded the Board that the mandate given to the architects included a provision that the building must harmonize with the other buildings on the campus.

On September 9, I 953, Dr. Jones reported to the Board of Trustees that bids had been opened on September I for less than the $\$ 4,000,000$ appropriated for the library. From October 23, I 953 to June I, I 956, the library was built; the formal dedication took place on Saturday, November 17, I 956.

The articles by Silver and pressure by Ed Wilkens may have given impetus to the feeling that the time was appropriate for a change. The fact that the trustees on April I 8th stated that the architecture of the new library ". . . need not conform to the Georgian pattern . . ." could not be attributed to the first Targum article on that date. The additional articles may have hardened their resolve. Be that as it may, the fact that Rutgers was soon to begin its most significant and largest expansion program made the shift even more important. That Doc Wilkens' papers and drawings, spanning 30 years of New Jersey planning and Rutgers history now repose in the Alexander Library, is both fitting and appropriate.

Welcome home, Doc! 